\title{
Purine-Metabolizing Ectoenzymes Control IL-8 Production in Human Colon HT-29 Cells
}

\author{
Fariborz Bahrami, ${ }^{1,2}$ Filip Kukulski, ${ }^{1,2}$ Joanna Lecka, ${ }^{1,2}$ Alain Tremblay, ${ }^{2}$ Julie Pelletier, ${ }^{2}$ \\ Liliana Rockenbach, ${ }^{1,2}$ and Jean Sévigny ${ }^{1,2}$ \\ ${ }^{1}$ Département de Microbiologie-Infectiologie et d'Immunologie, Faculté de Médecine, Université Laval, Québec, QC, Canada G1V 0A6 \\ ${ }^{2}$ Centre de Recherche du CHU de Québec, 2705 Boulevard Laurier, Local T1-49, Québec, QC, Canada G1V 4G2
}

Correspondence should be addressed to Jean Sévigny; jean.sevigny@crchul.ulaval.ca

Received 29 May 2014; Accepted 3 July 2014; Published 23 July 2014

Academic Editor: Mireia Martín-Satué

Copyright (c) 2014 Fariborz Bahrami et al. This is an open access article distributed under the Creative Commons Attribution License, which permits unrestricted use, distribution, and reproduction in any medium, provided the original work is properly cited.

\begin{abstract}
Interleukin-8 (IL-8) plays key roles in both chronic inflammatory diseases and tumor modulation. We previously observed that IL-8 secretion and function can be modulated by nucleotide (P2) receptors. Here we investigated whether IL- 8 release by intestinal epithelial HT-29 cells, a cancer cell line, is modulated by extracellular nucleotide metabolism. We first identified that HT-29 cells regulated adenosine and adenine nucleotide concentration at their surface by the expression of the ectoenzymes NTPDase2, ecto$5^{\prime}$-nucleotidase, and adenylate kinase. The expression of the ectoenzymes was evaluated by RT-PCR, qPCR, and immunoblotting, and their activity was analyzed by RP-HPLC of the products and by detection of $\mathrm{P}_{\mathrm{i}}$ produced from the hydrolysis of ATP, ADP, and AMP. In response to poly (I:C), with or without ATP and/or ADP, HT-29 cells released IL-8 and this secretion was modulated by the presence of NTPDase 2 and adenylate kinase. Taken together, these results demonstrate the presence of 3 ectoenzymes at the surface of HT-29 cells that control nucleotide levels and adenosine production (NTPDase2, ecto- $5^{\prime}$-nucleotidase and adenylate kinase) and that P2 receptor-mediated signaling controls IL-8 release in HT-29 cells which is modulated by the presence of NTPDase2 and adenylate kinase.
\end{abstract}

\section{Introduction}

Inflammation is a major contributor to the development and progression of many human cancers [1] and is obviously a key constituent of inflammatory diseases such as inflammatory bowel diseases (IBD) [2-4]. Indeed, a number of chronic inflammatory conditions increase the risk of developing cancers [5]. For instance, IBD is associated with an increased risk of colon cancer development $[6,7]$. In addition, the long-term use of anti-inflammatory drugs such as aspirin decreases the risk of several cancer types [8].

Interleukin-8 (IL-8) or CXCL8 is a proinflammatory chemokine originally identified as a neutrophil chemoattractant [9], which is an important contributor to the induction of innate immunity [10]. Accordingly, IL-8 has been implicated in a number of inflammatory diseases such as IBD [11, 12]. Elevated IL-8 signaling has also been observed within the tumor microenvironment of numerous cancers where it enhances tumor progression via the activation of pathways that promote proliferation, angiogenesis, migration, invasion, and cell survival $[13,14]$. Altogether, this suggests that inhibition of IL-8 production could be a potential treatment for both chronic inflammatory diseases and cancer $[13,15]$. Therefore, a better understanding of the mechanisms that drive or mediate IL-8 release is imperative.

We have previously observed that IL- 8 secretion, and even function, can be controlled by nucleotide receptors [16-18]. Extracellular nucleotides (e.g., ATP, ADP, UTP, and UDP) are secreted by host cells in response to injury, such as in conditions of inflammation, and act as danger signals (alarmins) and damage-associated molecular patterns (DAMPs). These substances initiate the host immune responses [19-21] by activating specific $\mathrm{P} 2$ receptors [22]. The concentration of $\mathrm{P} 2$ receptor agonists is regulated by ectoenzymes that metabolize nucleotides [23-26]. While ectonucleotidases such as nucleoside triphosphate diphosphohydrolases (NTPDases) 
generally terminate P2 receptor activation [24], nucleotide kinases such as adenylate kinase (ADK) may potentiate P2 activation by regenerating the ligand of these receptors from the products of ectonucleotidases [27-29].

In this work, we used HT-29 colon cancer cell line as a model of intestinal epithelial cells (used in IBD models) as well as a model of cancer cells to investigate if, in such cells, ectoenzymes that modulate nucleotide metabolism can control IL-8 secretion. Indeed, HT-29 cells express and secrete IL- 8 in response to diverse stimuli $[30,31]$ such as TLR3 agonists [32]. They also express functional receptors that respond to ATP and/or UTP [33-35] as well as to adenosine [36-42] that are involved in several functions including cell growth and differentiation, and IL-8 release. Our initial objective was therefore to characterize the expression of nucleotide metabolizing ectoenzymes. We identified 3 of these enzymes and 2 of them affected IL- 8 release in our system: NTPDase2 which is a predominant ATPase [43] and $\mathrm{ADK}$ that catalyzes the reversible transphosphorylation reaction leading to ATP and AMP production from two molecules of ADP as substrate [23]. The ecto- $5^{\prime}$-nucleotidase that hydrolyses AMP into adenosine $[44,45]$ was also highly expressed in these cells.

\section{Materials and Methods}

2.1. Materials. DMEM/F-12 growth medium, Glutamax, $\mathrm{Hu}$ IL-8 Cytoset ELISA kit, PureLink Genomic DNA mini kit, Quant-iT RNA BR assay kit, NuPAGE Novex 4-12\% BisTris gel, TRIzol reagent, DNAsel-RNAse-free (AM2222), Superscript III reverse transcriptase, RNAseOUT recombinant Ribonuclease inhibitor, dNTP, DTT, aprotinin, Lipofectamine, microAMp optical 384 well reaction plate, custommade primers, and $1 \mathrm{~kb}$ plus DNA ladder were purchased from Life Technologies (Burlington, ON, Canada). Normocin was obtained from InvivoGen (San Diego, CA, USA). ATP, ADP, AMP, adenosine, ATP- $\gamma$-S, suramin, diadenosine pentaphosphate $\left(\mathrm{Ap}_{5} \mathrm{~A}\right)$, malachite green, and random nonamers (R7647) were purchased from Sigma. Millex GP syringedriven filter unit $0.22 \mu \mathrm{m}$ and Immobilon-P membrane were from Millipore (Billerine, MA, USA). Hank's balanced salt solution (HBSS) with $\mathrm{Ca}^{2+}$ and $\mathrm{Mg}^{2+}$, Hepes, and antibioticantimycotic solutions was from Wisent (St. Bruno, QC, Canada). RNeasy mini kit and QuantiTect Reverse Transcription kit were from Qiagen (Mississauga, ON, Canada). Taq polymerase was obtained from New England Biolabs (Ipswich, MA, USA) and FastStart Universal SYBR Green Master (Rox) was from Roche (Mannheim, Germany).

2.2. Cell Culture and Treatment. HT-29 (ATCC ${ }^{\circledR} \mathrm{HTB}_{-38^{\mathrm{TM}}}$ ) human colon adenocarcinoma cell line was purchased from the American Type Culture Collection and maintained in monolayer cultures in DMEM/F-12 growth medium supplemented with Glutamax $(2 \mathrm{mM})$, antibiotic-antimycotic solution (1X), Hepes (25 mM), Normocin (used as an antimycoplasma reagent, $100 \mu \mathrm{g} / \mathrm{mL}$ ), and $10 \%$ heat-inactivated fetal bovine serum at $37^{\circ} \mathrm{C}$ in a $95 \%$ air: $5 \% \mathrm{CO}_{2}$ atmosphere. Cells were regularly monitored for the presence of Mycoplasma spp. by means of a conventional PCR test [47] using $5 \mu \mathrm{g}$ of extracted genomic DNA (PureLink genomic DNA mini kit) as a template. The cells from passages $2-3$ were seeded $\left(2 \times 10^{6} /\right.$ well $)$ in 24 -well plates containing $1 \mathrm{~mL}$ medium. For cell counting and subculturing, cells were dispersed with a $0.25 \%$ trypsin solution. Cell viability always exceeded $95 \%$, as measured by Trypan blue dye exclusion.

2.3. IL-8 Production Assays. HT-29 cells were stimulated with suboptimal concentration of poly (I:C) alone or in presence of nucleotides with or without $\mathrm{Ap}_{5} \mathrm{~A}$ as an $\mathrm{ADK}$ inhibitor. Stimulations were carried out for $18 \mathrm{~h}$. Media were then collected and centrifuged to remove detached cells and were analyzed for the detection of human IL-8 using the Human IL-8 CytoSet ELISA kit.

2.4. RP-HPLC. HT-29 cells were incubated with ADP or ATP (both at $100 \mu \mathrm{M}$ ) in Hank's balanced salt solution (HBSS) containing $\mathrm{Ca}^{2+}$ and $\mathrm{Mg}^{2+}$. Where indicated, these incubations were carried out in the presence of the ADK inhibitor, $\mathrm{Ap}_{5} \mathrm{~A}(10 \mu \mathrm{M})$. At the indicated time points, $100 \mu \mathrm{L}$ aliquots of medium were sampled, deproteinized with an equal volume of PCA (1 M), and neutralized with $\mathrm{KOH}(1 \mathrm{M})$, with all solutions being kept at $4^{\circ} \mathrm{C}$. Analysis of the reaction products was performed by RP-HPLC using $15 \mathrm{~cm} \times 3.6 \mathrm{~mm}$, $3 \mu \mathrm{m}$ SUPELCOSIL LC-18-T columns (Supelco) as described previously [43].

2.5. RT-PCR. Total RNA was purified from HT-29 cells using the RNeasy mini kit and quantified with a Quant-iT RNA BR assay kit and Qubit fluorometer (Life Technologies). The cDNA was prepared using QuantiTect Reverse Transcription kit. For NTPDase screening, semiquantitative amplifications were done with $1 \mu \mathrm{L}$ cDNA prepared from $3 \mu \mathrm{g}$ total RNA and Taq polymerase using a PTC-200 Peltier Thermal Cycler in $25 \mu \mathrm{L}$ reaction volumes and the following program: (i) $2 \mathrm{~min}$ at $94^{\circ} \mathrm{C}$ and (ii) 20 cycles of $1 \mathrm{~min}$ at $94^{\circ} \mathrm{C}, 1 \mathrm{~min}$ at $75^{\circ} \mathrm{C}$ (and then decreasing by $1^{\circ} \mathrm{C} /$ cycle), and $1 \mathrm{~min}$ at $72^{\circ} \mathrm{C}$, followed by (iii) 30 cycles of $1 \mathrm{~min}$ at $94^{\circ} \mathrm{C}, 1 \mathrm{~min}$ at $60^{\circ} \mathrm{C}$, and $1 \mathrm{~min}$ at $72^{\circ} \mathrm{C}$ and (iv) a final $7 \mathrm{~min}$ step at $72^{\circ} \mathrm{C}$. For the positive controls, $10 \mathrm{pg}$ of miniprep DNA from the expression vectors used for cloning NTPDase1, -3 , and -8 were used as templates [48] and due to the location of the primers, $50 \mathrm{ng}$ of HT-29 genomic DNA was used for NTPDase2. For the negative controls, water was used as template. For P2Y receptor screening, using similar conditions for preparation, the program was (i) $2 \mathrm{~min}$ at $94^{\circ} \mathrm{C}$ and (ii) 20 cycles of $1 \mathrm{~min}$ at $94^{\circ} \mathrm{C}, 1 \mathrm{~min}$ at $72^{\circ} \mathrm{C}$ (and then decreasing by $1^{\circ} \mathrm{C} /$ cycle), and $1 \mathrm{~min}$ at $72^{\circ} \mathrm{C}$, followed by (iii) 20 cycles of $1 \mathrm{~min}$ at $94^{\circ} \mathrm{C}, 1 \mathrm{~min}$ at $57^{\circ} \mathrm{C}$, and $1 \mathrm{~min}$ at $72^{\circ} \mathrm{C}$ and (iv) a final 7 min step at $72^{\circ} \mathrm{C}$. For human AK1 $\beta$ amplification, total RNA was extracted and quantified as above, and the cDNA was prepared using $1 \mu \mathrm{g}$ RNA and Superscript III reverse transcriptase, as specified by the manufacturer. Semiquantitative amplifications were performed as above, except that the amplification program used was (i) $2 \mathrm{~min}$ at $94^{\circ} \mathrm{C}$, (ii) 35 cycles of $30 \mathrm{sec}$ at $94^{\circ} \mathrm{C}$, $30 \mathrm{sec}$ at $66.1^{\circ} \mathrm{C}$, and $30 \mathrm{sec}$ at $72^{\circ} \mathrm{C}$, and (iii) a final $7 \mathrm{~min}$ at $72^{\circ} \mathrm{C}$. Sequencing of the amplicons was performed by 
TABLE 1: RT-PCR primers.

\begin{tabular}{llll}
\hline Gene & Forward primer & Reverse primer & Amplicon (bp) \\
\hline$P 2 R Y 1$ & AAAACTAGCCCCCTGCAACT & GATCTGATGCCGGATGAACT & 153 \\
$P 2 R Y 2$ & CCACCTGCCTTCTCACTAGC & TGGGAAATCTCAAGGACTGG & 163 \\
$P 2 R Y 4$ & GCAGGGATATCATGGGTGAC & CCCAGGAAGGAACAGAAACA & 109 \\
$P 2 R Y 6$ & AGCTGGGCATGGAGTTAAGA & GCTGACTGGGACCTCTCAAG & 139 \\
$P 2 R Y 11$ & CCTCTACGCCAGCTCCTATG & CCTCTACGCCAGCTCCTATG & 211 \\
$P 2 R Y 12$ & TTTGCCCGAATTCCTTACAC & ATTGGGGCACTTCAGCATAC & 192 \\
$P 2 R Y 13$ & CCCCTGGTACACTTGGAAGA & TACAGAGGAGGGGGTGATTG & 125 \\
$P 2 R Y 14$ & TCTTTGGGCTCATCAGCTTT & TCCGTCCCAGTTCACTTTTC & 213 \\
$E N T P D 1$ & GCCAGCAGAAAAGGAGAATG & TGGGACCTTGGAATCACTTC & 159 \\
$E N T P D 2$ & TCAATCCAGCTCCTTGAACC & TCCCCAGTACAGACCCAGAC & 167 \\
$E N T P D 3$ & TTGACCTCAGGGCTCAGTTT & TGAGGGGGTTCACTGCTTAC & 107 \\
$E N T P D 8$ & ACTGGGCTACATGCTGAACC & GCACCATGAACACCACTTTG & 228 \\
GAPDH & CGACCACTTTGTCAAGCTCA & AGGGGTCTACATGGCAACTG & 412 \\
AK1 $\beta^{\mathrm{a}}$ & GGAATTCGACCATGGGCTGCTGCTC & GGAATTCGCAGCAGTGTGGGCTGTC \\
AK1 $\beta$ & ACAGGAGACACGGCAGGACGGGAC & CTCTTCTCCTTGCTGCACCTCC & 385 \\
\hline
\end{tabular}

${ }^{\mathrm{a}}$ Taken from reference [46].

automated DNA sequencing at the Plateforme de Génomique, Protéomique et Bio-informatique, CRCHU, Université Laval.

2.6. $q P C R$. Total RNA was purified from HT-29 cells using TRIzol reagent and following the manufacturer's instructions. RNA was quantified with a Quant-iT RNA BR assay kit and Qubit fluorometer. For synthesis of cDNA, $2 \mu \mathrm{g}$ of RNA was treated for $15 \mathrm{~min}$ at $20^{\circ} \mathrm{C}$ with 2 units of DNase I (RNasefree) in a volume of $10 \mu \mathrm{L}$, to remove contaminating DNA, followed by heat inactivation of the enzyme at $65^{\circ} \mathrm{C}$ for $10 \mathrm{~min}$ with $1 \mu \mathrm{L}$ of $25 \mathrm{mM}$ EDTA. Treated RNA was annealed with $1 \mu \mathrm{L}$ random nonamers with $1 \mu \mathrm{L}$ dNTP $(10 \mathrm{mM})$ and $1 \mu \mathrm{L}$ of water and heated at $65^{\circ} \mathrm{C}$ for $5 \mathrm{~min}$ and $1 \mathrm{~min}$ at $2^{\circ} \mathrm{C}$ in a PTC-200 Peltier thermal cycler. The cDNA was done with $1 \mu \mathrm{L}$ of Superscript III reverse transcriptase, $1 \mu \mathrm{L}$ of RNAseOUT, $1 \mu \mathrm{L}$ of $0.1 \mathrm{M} \mathrm{DTT}$, and $4 \mu \mathrm{L}$ of $5 \mathrm{X}$ FirstStrand Buffer, incubated in a PTC-200 Peltier Thermal cycler at $50^{\circ} \mathrm{C}$ for $60 \mathrm{~min}$, and inactivated at $70^{\circ} \mathrm{C}$ for $15 \mathrm{~min}$. For NTPDase mRNA evaluation, quantitative amplifications were done with $1 \mu \mathrm{L}$ cDNA, $5 \mu \mathrm{L}$ FastStart Universal SYBR Green Master (ROX), and $1 \mu \mathrm{L}$ of specific primers $(3 \mu \mathrm{M})$ in a MicroAMp optical 384-well reaction plate and using an Applied Biosystems 7900HT Fast Real-Time PCR system in $10 \mu \mathrm{L}$ reaction volumes and the following program: (i) $2 \mathrm{~min}$ at $50^{\circ} \mathrm{C}$, (ii) $10 \mathrm{~min}$ at $95^{\circ} \mathrm{C}$, (iii) 40 cycles of $15 \mathrm{sec}$ at $95^{\circ} \mathrm{C}, 1 \mathrm{~min}$ at $60^{\circ} \mathrm{C}$, and (iv) a dissociation stage. For the standard curve, 10 copies to $10^{8}$ copies of amplified fragment were used. For the negative controls, water was used as template. Each quantification was normalized with GAPDH. The primers used in this study for both RT-PCR and qRTPCR are presented in Table 1.

2.7. Cell Transfection and Protein Preparation. HEK 293 cells were cultured and transfected in $10 \mathrm{~cm}$ plate using
Lipofectamine as previously described [43]. Briefly, 80\%$90 \%$ confluent cells were incubated for $5 \mathrm{~h}$ at $37^{\circ} \mathrm{C}$ in Dulbecco's modified Eagle's medium (DMEM) in the absence of fetal bovine serum (FBS) with $6 \mu \mathrm{g}$ of plasmid DNA encoding for human ecto- $5^{\prime}$-nucleotidase (GenBank accession no. NM_002526) previously described [49] and $24 \mu \mathrm{L}$ of Lipofectamine reagent. The reaction was stopped by the addition of an equal volume of DMEM containing 20\% FBS and the cells were harvested $48 \mathrm{~h}$ later. For the preparation of protein extracts, transfected cells or HT-29 cells were washed three times with Tris-saline buffer at $4^{\circ} \mathrm{C}$ collected by scraping in the harvesting buffer $(95 \mathrm{mM} \mathrm{NaCl}, 0.1 \mathrm{mM}$ PMSF, and $45 \mathrm{mM}$ Tris at $\mathrm{pH} 7.5$ ) and washed twice by $300 \times \mathrm{g}$ centrifugation for $10 \mathrm{~min}$ at $4^{\circ} \mathrm{C}$. Cells were resuspended in the harvesting buffer containing $10 \mu \mathrm{g} / \mathrm{mL}$ aprotinin and sonicated. Nucleus and cellular debris were discarded by centrifugation at $600 \times \mathrm{g}$ for $5 \mathrm{~min}$ at $4^{\circ} \mathrm{C}$ and the supernatant (crude protein extract) was aliquoted and stored at $-80^{\circ} \mathrm{C}$ until used for experiments. Proteins concentrations were determined with a Quant-iT protein assay kit and Qubit fluorometer (Life Technologies).

2.8. Immunoblotting and Antibodies. Protein extract was resolved on a NuPAGE Novex $4-12 \%$ Bis-Tris gel and transferred to an Immobilon-P membrane by electroblotting according to the manufacturer's instructions (Millipore). The membrane was probed with the following antibodies: mouse anti-human NTPDasel (BU61, Ancell Corporation (Bayport, MN, USA)), guinea pig anti-human NTPDase1 $\left(\mathrm{hN} 1-1_{\mathrm{C}} \mathrm{I}_{5}\right)$, mouse monoclonal anti-human NTPDase2 (hN2$\mathrm{B} 2_{\mathrm{s}}$ and $\mathrm{hN} 2-\mathrm{H} 9_{\mathrm{s}}$ ), guinea pig anti-human NTPDase3 (hN3$\left.1_{\mathrm{C}} \mathrm{I}_{5}\right)$, mouse monoclonal anti-human NTPDase3 (hN3-B3 $\mathrm{s}$ ), mouse anti-human NTPDase $8\left(\mathrm{hN} 8-6_{\mathrm{s}} \mathrm{I}_{6}\right)$, mouse monoclonal anti-human NTPDase8 (hN8-D7 $)$, rabbit anti-human ecto- $5^{\prime}$-nucleotidase $\left(\mathrm{h} 5^{\prime} \mathrm{NT}-2_{\mathrm{L}} \mathrm{I}_{5}\right)$, guinea pig anti-human 
ecto- $5^{\prime}$-nucleotidase (h5 ${ }^{\prime} \mathrm{NT}-2_{\mathrm{c}} \mathrm{I}_{5}$ ), and the mouse monoclonal anti-human ecto- $5^{\prime}$-nucleotidase (clone 4G4, Hycult Biotech, Plymouth Meeting, PA, USA). All antibodies, except the mouse monoclonal anti-human NTPDasel BU61 and the mouse anti-human ecto- $5^{\prime}$-nucleotidase clone $4 \mathrm{G} 4$, were produced by $\mathrm{cDNA}$ immunization in our laboratory and their specificities were confirmed by immunoblots and immunohistochemistry $[48,50,51]$. These antibodies are available at http://ectonucleotidases-ab.com/. The secondary horseradish peroxidase-conjugated antibodies used were goat anti-mouse (Jackson Immuno Research Laboratories Inc., West Grove, PA, USA), donkey anti-rabbit (GE Healthcare Life Sciences, Baie d'Urfe, Québec, Canada), and goat anti-guinea pig (Santa Cruz Biotechnology, Dallas, TX, USA). The blots were developed with the Western Lightning Plus-ECL reagent (PerkinElmer Life and Analytical Sciences, Waltham, MA, USA).

2.9. Enzymatic Reactions. Enzyme activity was evaluated as described [43] in $0.2 \mathrm{~mL}$ of Tris-Ringer buffer (in mM: 120 $\mathrm{NaCl}, 5 \mathrm{KCl}, 2.5 \mathrm{CaCl}_{2}, 1.2 \mathrm{MgSO}_{4}, 25 \mathrm{NaHCO}_{3}, 5 \mathrm{D}$-glucose, and 80 Tris; $\mathrm{pH} \mathrm{7.4)}$ at $37^{\circ} \mathrm{C}$. HT-29 lysates were added to the incubation mixture and preincubated at $37^{\circ} \mathrm{C}$ for $3 \mathrm{~min}$. The reaction was initiated by the addition of $500 \mu \mathrm{M}$ ATP, ADP, or AMP and stopped after $10-15$ min with $50 \mu \mathrm{L}$ of malachite green reagent. The activity at the cell surface was measured with confluent HT-29 cells in 24-well plates (about 200,000 cells per well). Cells were maintained in Dulbecco's modified Eagle medium nutrient mixture F-12 (DMEM-F12) supplemented with 10\% FBS until conducting the activity assay that was performed in the buffer indicated above. The reactions were initiated as above and stopped by transferring an aliquot of the reaction mixture to a tube containing the malachite green reagent. Net cell-bound enzyme activity was calculated after subtracting the value measured in the control cell reaction mixture where the substrate was added after the malachite green reagent. Released inorganic phosphate $\left(\mathrm{P}_{\mathrm{i}}\right)$ was measured at $630 \mathrm{~nm}$ according to Baykov et al. [52]. All experiments were performed in triplicate.

One unit of enzymatic activity corresponds to the release of $1 \mu \mathrm{mol} \mathrm{P}_{\mathrm{i}} /\left(\mathrm{min} \cdot \mathrm{mg}\right.$ of protein) or $1 \mu \mathrm{mol} \mathrm{P}_{\mathrm{i}} / \mathrm{min} /$ well at $37^{\circ} \mathrm{C}$ for protein extracts and intact cells, respectively.

2.10. Statistical Analysis. Two-tailed Student's $t$-test was performed using the Microsoft 2007 Excel software. $P<0.05$ was considered statistically significant.

\section{Results}

3.1. HT-29 Cells Express Purine-Metabolizing Ectoenzymes. Our initial goal was to define the ectonucleotidases expressed in HT-29 cells. This was first done by investigating the metabolism of extracellular ATP and ADP by these cells. The analysis of ATP hydrolysis products showed a significant accumulation of ADP (Figure 1(a)), which fits the profile expected for NTPDase2 activity [43]. In agreement, semiquantitative PCR using primers specific to human NTPDase members expressed at the plasma membrane, namely,
NTPDase1, -2, -3 , and -8, showed high expression of NTPDase2 in HT-29 cells (Figure 1(b)). This was further confirmed by quantitative RT-PCR (Figure 1(c)). Immunoblotting experiments using 2 different sets of antibodies to human NTPDase1, $-2,-3$, and -8 with protein samples extracted from HT-29 cells were consistent with the PCR results and confirmed the predominant presence of NTPDase 2 in these cells (Figure 1(d) for one set of antibody and data not shown for the guinea pig anti-human NTPDasel $\left(\mathrm{hN1}-\mathrm{1}_{\mathrm{C}} \mathrm{I}_{5}\right)$, mouse monoclonal NTPDase2 (hN2-H9s), mouse monoclonal NTPDase3 $\left(\mathrm{hN} 3-\mathrm{B} 3_{\mathrm{s}}\right)$, and mouse monoclonal NTPDase8 (hN8-D7s) antibodies; see Section 2).

RP-HPLC analyses further revealed that HT-29 cells have the ability to produce ATP when incubated with ADP (Figure 2(a)). This implied the presence of an adenylate kinase $(\mathrm{ADK})$ activity, which catalyzes the reversible reaction: $2 \mathrm{ADP} \rightleftharpoons \mathrm{ATP}+\mathrm{AMP}$. The amount of ATP produced varied according to ADP concentration (Figure 2(b)). To confirm that this activity belonged to ecto-ADK, we tested whether $\mathrm{Ap}_{5} \mathrm{~A}$, a specific inhibitor of this enzyme, might affect ATP production. As shown in the inset of Figure 2(a), the production of ATP from ADP was inhibited by $\mathrm{Ap}_{5} \mathrm{~A}$. Semiquantitative RT-PCR using a published set of primers [46] (data not shown) as well as a home-made set designed from EST clone 781374 (NCBI accession number: AA430294; cf. Table 1), together with the subsequent sequencing of the amplicons, showed that HT-29 cells express $A K 1 \beta$, which encodes the plasma membrane-localized isoform of $\mathrm{ADK}$ (Figure 2(e)).

Interestingly, the presence of $\mathrm{ADK}$ activity at the surface of HT-29 cells allowed adenosine production in the presence of either ATP (hydrolyzed to ADP by NTPDase2) or ADP. Indeed, adenosine production was prevented by the ADK inhibitor $\mathrm{Ap}_{5} \mathrm{~A}$ (Figures 2(c) and 2(d)). As ATP and ADP, adenosine is of important biological value due to the various functions affected by this P1 receptor ligand. The production of adenosine cannot be explained by neither NTPDase 2 nor ADK alone. Therefore the data presented in Figures 1(a), 2(a), 2 (c), and 2(d) suggested the presence of ecto- $5^{\prime}$-nucleotidase which was confirmed by 3 different antibodies that showed the same immunoreactive band (Figure 2(f); data not shown for the guinea pig anti-human ecto- $5^{\prime}$-nucleotidase antibody; see Section 2). Finally, the hydrolysis of ATP, ADP, and AMP was also evaluated at the surface of HT-29 cells as well as with protein extracts which confirmed the presence of enzymes able to hydrolyze ATP and AMP as substrate (Table 2), in agreement with the presence of NTPDase 2 and ecto- $5^{\prime}$ nucleotidase.

3.2. NTPDase 2 and ADK Affect IL-8 Production. We then addressed the hypothesis that the purine-metabolizing enzymes expressed at the surface of HT-29 cells can affect the release of IL-8. As ATP and ADP alone did not activate IL-8 release, these assays were performed in the presence of a suboptimal concentration of poly (I:C) which is a TLR3 agonist. TLR3 activation was selected for the following reasons. TLR3 activation stimulates IL-8 release in HT-29 cells [32] in a nucleotide dependent manner (manuscript in 


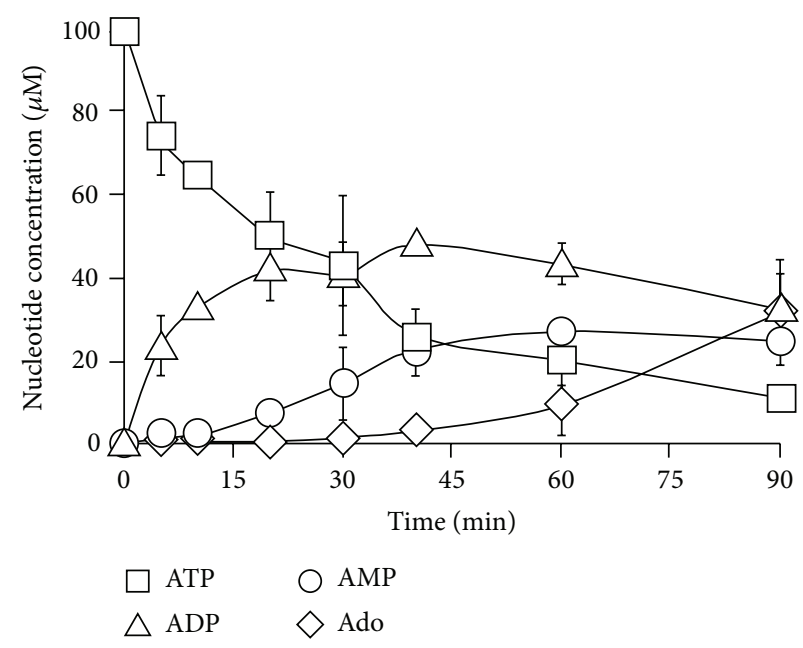

(a)

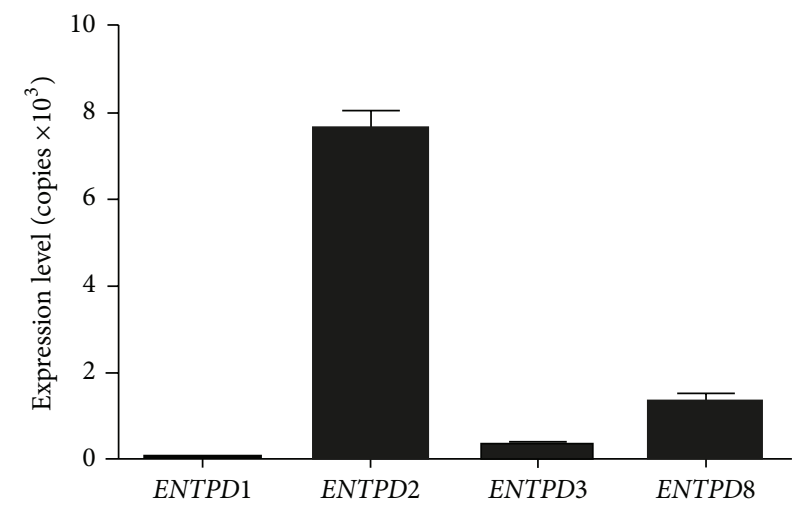

(c)

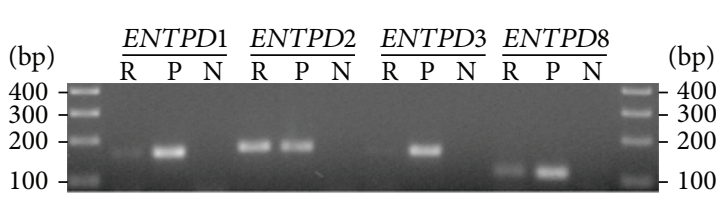

(b)
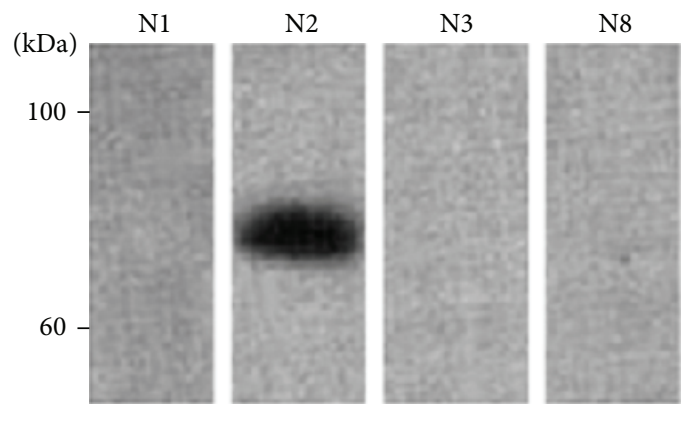

(d)

Figure 1: NTPDase2 is expressed by HT-29 cells. (a) HT-29 cells were incubated with ATP for 90 min and their supernatants were then subjected to RP-HPLC to quantify the various ATP degradation products $(n=3)$. (b) The expression of various human NTPDase genes was analyzed by semiquantitative RT-PCR where R, P, and N represent the reaction with HT-29 cells, the positive controls, and the negative controls, respectively, and (c) by quantitative RT-PCR $(n=5)$. (d) The expression of NTPDase proteins in HT-29 cells was analyzed by immunoblotting using specific antibodies to human NTPDase1, $-2,-3$, and -8, N1, N2, N3, and N8, respectively. A representative experiment of $n=4$ is shown.

TABLE 2: Adenine nucleotide hydrolysis at the surface of HT-29 cells and protein extracts.

\begin{tabular}{lcc}
\hline Activities & $\begin{array}{c}\text { Intact cells }(n=4) \\
{\left[\text { nmoles } \mathrm{P}_{\mathrm{i}} \cdot \mathrm{min}^{-1} \cdot \text { well }^{-1}\right]}\end{array}$ & $\begin{array}{c}\text { Cell lysates }(n=3) \\
{\left[\text { nmoles } \mathrm{P}_{\mathrm{i}} \cdot \min ^{-1} \cdot \mathrm{mg} \mathrm{prot}^{-1}\right]}\end{array}$ \\
\hline ATPase & $7.5 \pm 0.3$ & $115 \pm 4$ \\
ADPase & $1.5 \pm 0.01$ & $38 \pm 1$ \\
AMPase & $6.5 \pm 0.3$ & $67 \pm 3$ \\
\hline
\end{tabular}

The hydrolysis of ATP, ADP, and AMP as substrate was performed and the liberated $\mathrm{P}_{\mathrm{i}}$ was determined by the malachite green assay as detailed in Section 2.

preparation). In addition, TLR3 was found to be involved in different cancers $[53,54]$ and was also reported to affect intestinal inflammation in a complex manner depending on the conditions, either protecting from inflammation or causing epithelial destruction [55-59].

In agreement with a role of ADK in IL-8 release by ATPor ADP-stimulated HT-29 cells, $\mathrm{Ap}_{5} \mathrm{~A}$ significantly diminished IL- 8 release induced by either nucleotide (Figure 3 ). As expected, $\mathrm{Ap}_{5} \mathrm{~A}$ did not affect IL- 8 release triggered by ATP$\gamma$-S (Figure 3), a nonhydrolysable ATP analogue, suggesting that the reduction in ATP-induced IL-8 secretion seen in the presence of the ADK inhibitor was due to the hydrolysis of ATP to ADP catalyzed by NTPDase2. This experiment also confirmed that the effect of $\mathrm{Ap}_{5} \mathrm{~A}$ on IL-8 release was specific to $\mathrm{ADK}$ inhibition as $\mathrm{Ap}_{5} \mathrm{~A}$ did not affect the poor induction of IL- 8 release by ATP- $\gamma$-S. In this system, adenosine did not affect IL- 8 release when HT-29 cells were stimulated with the TLR3 agonist poly (I:C) (data not shown), suggesting that, in these conditions with this cell line, ecto- $5^{\prime}$-nucleotidase did not affect IL-8 production and release. 


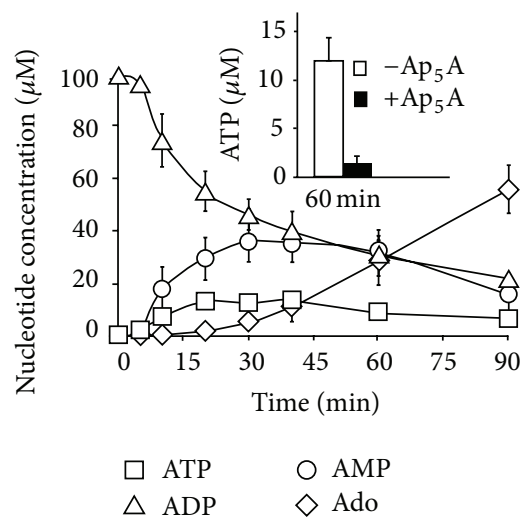

(a)

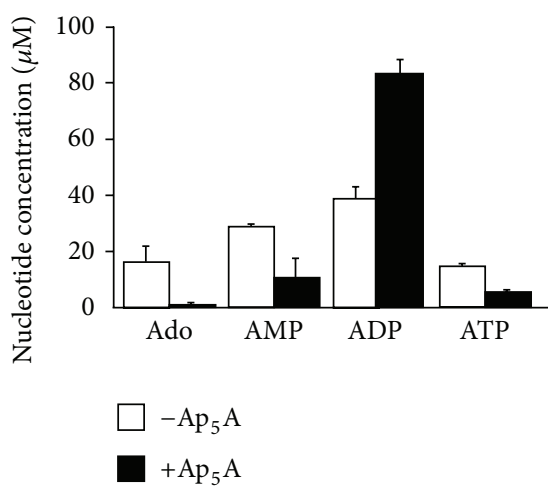

(c)

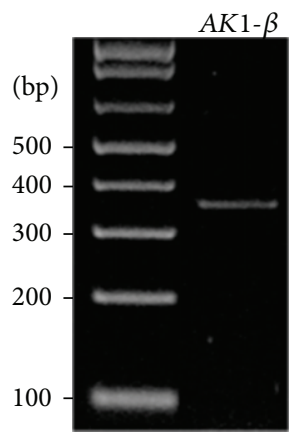

(e)

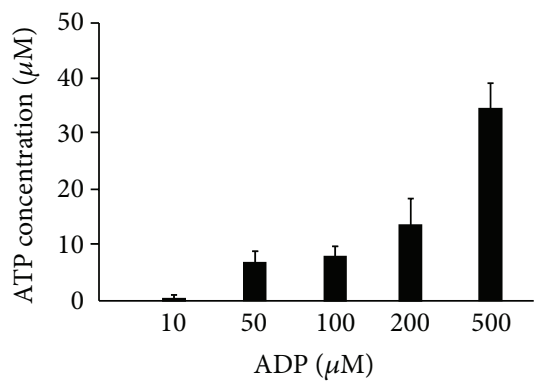

(b)

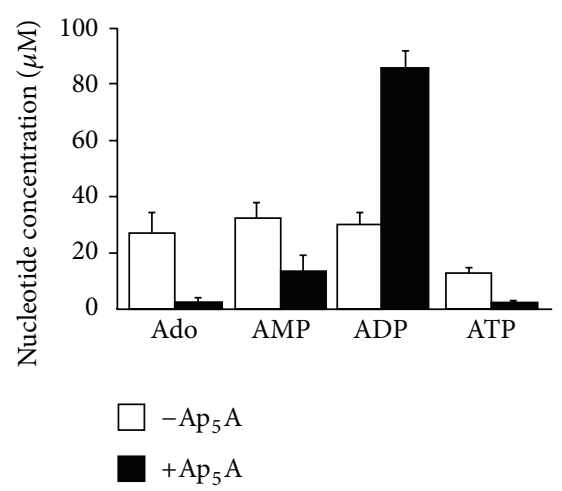

(d)
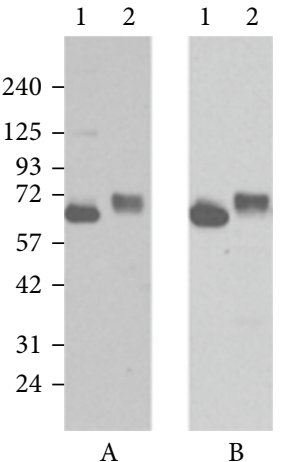

(f)

Figure 2: Adenylate kinase and ecto- $5^{\prime}$-nucleotidase are expressed by HT-29 cells. (a) HT-29 cells were incubated with ADP for 90 min and their supernatants were subjected to RP-HPLC for the determination of purines and ADK activity $(n=3)$. Inset shows the effect of the ADK inhibitor, $\mathrm{Ap}_{5} \mathrm{~A}$, on ATP production by HT-29 cells after $1 \mathrm{~h}(n=3)$. (b) Supernatants from HT-29 cells incubated for 30 min with various concentrations of ADP were subjected to RP-HPLC to determine ATP production $(n=3)$. ((c), (d)) Supernatants from HT-29 cells incubated for 30 min with either $100 \mu \mathrm{M} \mathrm{ATP} \mathrm{((c)} n=2)$ or ADP $((\mathrm{d}) n=3)$, in the presence of $10 \mu \mathrm{M} \mathrm{Ap} \mathrm{A}_{5}$ or control vehicle, were subjected to RP-HPLC for the determination of adenine nucleotide and adenosine byproducts. (e) Semiquantitative RT-PCR analysis on HT-29 cell line showing the presence of the membrane associated adenylate kinase. A representative experiment of $n=2$ is presented. (f) The expression of ecto- $5^{\prime}$-nucleotidase protein was detected by immunoblotting with the rabbit anti-human ecto- $5^{\prime}$-nucleotidase h5 $5^{\prime} \mathrm{NT}-2_{\mathrm{L}} \mathrm{I}_{5}((\mathrm{~A})$ on the left side) and with the commercial antibody clone 4G4 ((B) on right side). For panels (A) and (B), lane 1 represents the positive control of protein extract $(6 \mu \mathrm{g})$ from HEK 293 cells transiently transfected with a human ecto- $5^{\prime}$-Nucleotidase expression vector and lane 2 protein extract $(20 \mu \mathrm{g})$ from HT-29. 


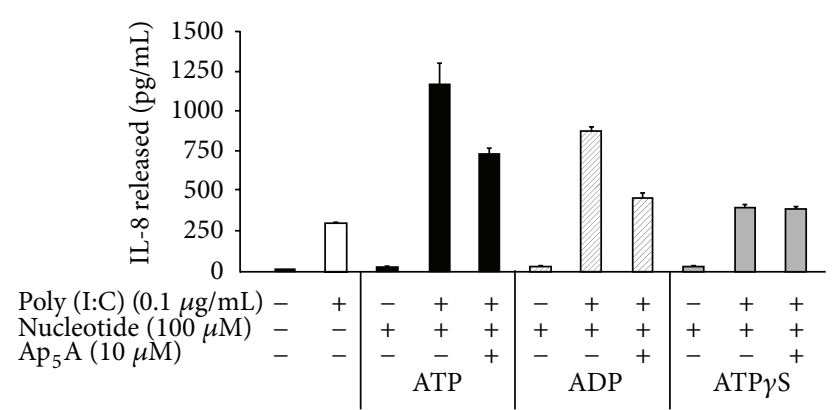

FIGURE 3: NTPDase2 and ADK modulate IL-8 production in HT29 cells. HT-29 cells were stimulated for $18 \mathrm{~h}$ with suboptimal concentration of poly (I:C) in combination with ATP, ADP, or the nonhydrolyzable ATP analog, ATP- $\gamma$-S, in the presence or absence of the ADK inhibitor, $\mathrm{Ap}_{5} \mathrm{~A}$. The cell supernatants were then analyzed for IL- 8 by ELISA $(n=3)$.

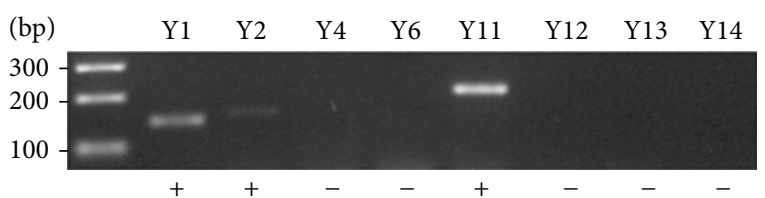

FIGURE 4: Comparative expression of human P2Y receptors in HT29 cells by semiquantitative RT-PCR. A representative experiment of $n=2$ is shown. Presence $(+)$ of $\mathrm{P}_{2} \mathrm{Y}_{1}, \mathrm{P}_{2} \mathrm{Y}_{2}$, and $\mathrm{P} 2 \mathrm{Y}_{11}$ was detected while the other $\mathrm{P} 2 \mathrm{Y}$ receptors were not detected $(-)$.

3.3. HT-29 Cells Express P2Y Receptors. We then analyzed the repertoire of P2Y receptors expressed in HT-29 cells by semiquantitative PCR. As seen in Figure 4, HT-29 cells express $\mathrm{P}_{2} \mathrm{Y}_{1}, \mathrm{P}_{2} \mathrm{Y}_{2}$, and $\mathrm{P} 2 \mathrm{Y}_{11}$. No, or very little, mRNA expression could be detected for the other P2Y receptors.

\section{Discussion}

The production of IL- 8 by HT-29 cells was affected by two ectoenzymes present at the surface of these cells, namely, ADK and NTPDase2. ADK activity increased the effects of exogenous ATP and ADP on IL-8 release in cells stimulated with a low concentration of poly (I:C). Indeed, the inhibition of $\mathrm{ADK}$ by $\mathrm{Ap}_{5} \mathrm{~A}$ decreased IL- 8 release promoted by these nucleotides. The $\mathrm{Ap}_{5} \mathrm{~A}$-dependent inhibition of IL8 production triggered by exogenous ATP also suggests an involvement of NTPDase2, which provides a substrate for ADK through the hydrolysis of ATP to ADP. In contrast to NTPDase2, one might expect that such a significant potentiation of IL-8 release would not be possible if ADK was coupled with either NTPDase1, -3 , or -8 which hydrolyze $\mathrm{ADP}$ and would therefore compete with $\mathrm{ADK}$ for this substrate. In agreement with the role of ADK in HT-29 cells, this enzyme present in lung epithelial cells also transiently maintains the increased concentration of ATP that can favor the activation of $\mathrm{P} 2$ receptors specific for that nucleotide [60]. $\mathrm{ADK}$ also promotes lymphocyte transendothelial migration by maintaining a significant level of ATP near the surface of these cells (halo ATP) [61].
We also observed that the ADK and NTPDase 2 pair expressed in HT-29 cells makes the production of adenosine possible. Indeed, while NTPDase 2 is required for ADP production from ATP, ADK converts two molecules of ADP to ATP and AMP. The latter is the substrate of ecto- $5^{\prime}$ nucleotidase that converts it to adenosine which was detected in the cell supernatant of HT-29 cells (Figures 2(a), 2(c), and $2(\mathrm{~d})$ ). Adenosine production is of great physiological importance due to the large variety of functions played by the activation of $\mathrm{P} 1$ receptors in all tissues and cells, which includes key functions in the regulation of inflammation $[62,63]$.

Surprisingly, the presence of adenosine made possible by $\mathrm{ADK}$ and ecto- $5^{\prime}$-nucleotidase did not affect IL- 8 release in our conditions. We first anticipated that adenosine would affect IL-8 production in HT-29 cells. Indeed, in conditions of inflammation induced by TNF- $\alpha$, the activation of the adenosine receptor $\mathrm{A}_{3}$ was previously shown to inhibit IL8 expression through the inhibition of $\mathrm{NF}-\kappa \mathrm{B}$ signaling pathways [37]. It is noteworthy that the secretion of IL- 8 by adenosine appears to depend on experimental conditions in HT-29 cells as the adenosine receptor agonist NECA was also reported to induce a small IL-8 release under severe hypoxia via $A_{2 B}$ [38]. Nevertheless, while we found that NTPDase2 and ADK ectoenzymes could affect IL- 8 release, our data also suggest that in other conditions, IL- 8 secretion could also be potentially affected by the presence of ecto- $5^{\prime}$-nucleotidase. In addition, as IL- 8 is also produced by other epithelial cells in an ATP dependent fashion [64], such a regulation of nucleotide signaling by ectoenzymes is also possible in other cells.

Importantly, the presence of adenosine made possible by the presence of ADK and ecto- $5^{\prime}$-nucleotidase could affect other functions in HT-29 cells. For example, adenosine increases HT-29 cells proliferation [39] via the activation of $A_{3}$ receptor $[36,42]$. The $A_{3}$ receptor was the most expressed adenosine receptor in human colon cancer tissues and in colon cell lines such as HT-29 cells [42]. Interestingly caffeine, a $\mathrm{P} 1$ receptor antagonist, has been associated with a reduced risk of colorectal cancer in a number of case-control studies [38] which suggest an important role of adenosine and of ecto- $5^{\prime}$-nucleotidase in colorectal cancer development.

\section{Conclusions}

HT-29 cells regulate adenine nucleotide levels by the combined action of NTPDase 2 , ADK, and ecto- $5^{\prime}$-nucleotidase. This combination of ectoenzymes allows the generation of adenosine from secreted ATP while keeping ATP level high for a longer period of time. This also permits a sustained $\mathrm{P} 2$ receptor activation leading to IL- 8 secretion which would normally be stopped rapidly by NTPDase 2 if ADK was absent. These mechanisms of regulation of IL-8 release observed in this human cancer intestinal epithelial cell line might well play an important role in tumor progression as well as in the pathology of IBD and other related inflammatory disorders. If also present in primary cells, the underlining mechanism of IL-8 production identified in this 
work presents a new pathway that may be targeted in some of these associated diseases.

\section{Conflict of Interests}

The authors state no conflict of interests.

\section{Acknowledgments}

This work was supported by Grants to J. Sévigny from the Canadian Institutes of Health Research (CIHR; MOP93683). F. Bahrami was a recipient of a fellowship from the CIHR/Wyeth Pharmaceuticals and J. Sévigny of a "Chercheur National" award from the Fonds de Recherche du QuébecSanté (FRQS). The authors thank Dr. Richard Poulin (Scientific Proofreading and Writing Service, CHUQ Research Center) for editing a preliminary version of this paper.

\section{References}

[1] D. Hanahan and R. A. Weinberg, "Hallmarks of cancer: the next generation," Cell, vol. 144, no. 5, pp. 646-674, 2011.

[2] M. D. Kappelman, S. L. Rifas-Shiman, K. Kleinman et al., "The Prevalence and Geographic Distribution of Crohn's Disease and Ulcerative Colitis in the United States," Clinical Gastroenterology and Hepatology, vol. 5, no. 12, pp. 1424-1429, 2007.

[3] M. D. Kappelman, S. L. Rifas-Shiman, C. Q. Porter et al., "Direct health care costs of Crohn's disease and ulcerative colitis," Gastroenterology, vol. 135, no. 6, pp. 1907-1913, 2008.

[4] A. Kaser, S. Zeissig, and R. S. Blumberg, "Inflammatory bowel disease," Annual Review of Immunology, vol. 28, pp. 573-621, 2010.

[5] A. M. de Marzo, T. L. DeWeese, E. A. Platz et al., "Pathological and molecular mechanisms of prostate carcinogenesis: implications for diagnosis, detection, prevention, and treatment," Journal of Cellular Biochemistry, vol. 91, no. 3, pp. 459-477, 2004.

[6] R. B. Gupta, N. Harpaz, S. Itzkowitz et al., "Histologic inflammation is a risk factor for progression to colorectal neoplasia in ulcerative colitis: a cohort study," Gastroenterology, vol. 133, no. 4, pp. 1099-1105, 2007.

[7] J. K. Triantafillidis, G. Nasioulas, and P. A. Kosmidis, "Colorectal cancer and inflammatory bowel disease: epidemiology, risk factors, mechanisms of carcinogenesis and prevention strategies," Anticancer Research, vol. 29, no. 7, pp. 2727-2737, 2009.

[8] E. Flossmann and P. M. Rothwell, "Effect of aspirin on longterm risk of colorectal cancer: consistent evidence from randomised and observational studies," The Lancet, vol. 369, no. 9573, pp. 1603-1613, 2007.

[9] K. Matsushima, K. Morishita, T. Yoshimura et al., "Molecular cloning of a human monocyte-derived neutrophil chemotactic factor (MDNCF) and the induction of MDNCF mRNA by interleukin 1 and tumor necrosis factor," The Journal of Experimental Medicine, vol. 167, no. 6, pp. 1883-1893, 1988.

[10] H. U. Zeilhofer and W. Schorr, "Role of interleukin-8 in neutrophil signaling," Current Opinion in Hematology, vol. 7, no. 3, pp. 178-182, 2000.

[11] L. Mazzucchelli, C. Hauser, K. Zgraggen et al., "Expression of interleukin-8 gene in inflammatory bowel disease is related to the histological grade of active inflammation," The American Journal of Pathology, vol. 144, no. 5, pp. 997-1007, 1994.
[12] M. C. Grimm, S. K. O. Elsbury, P. Pavli, and W. F. Doe, "Interleukin 8: cells of origin in inflammatory bowel disease," Gut, vol. 38, no. 1, pp. 90-98, 1996.

[13] L. M. Campbell, P. J. Maxwell, and D. J. J. Waugh, "Rationale and means to target pro-inflammatory interleukin-8 (CXCL8) signaling in cancer," Pharmaceuticals, vol. 6, no. 8, pp. 929-959, 2013.

[14] N. de la Iglesia, G. Konopka, K. Lim et al., "Deregulation of a STAT3-interleukin 8 signaling pathway promotes human glioblastoma cell proliferation and invasiveness," Journal of Neuroscience, vol. 28, no. 23, pp. 5870-5878, 2008.

[15] P. Zarogoulidis, F. Katsikogianni, T. Tsiouda, A. Sakkas, N. Katsikogiannis, and K. Zarogoulidis, "Interleukin- 8 and interleukin-17 for cancer," Cancer Investigation, vol. 32, no. 5, pp. 197-205, 2014.

[16] F. Kukulski, F. B. Yebdri, J. Lefebvre, M. Warny, P. A. Tessier, and J. Sévigny, "Extracellular nucleotides mediate LPS-induced neutrophil migration in vitro and in vivo," Journal of Leukocyte Biology, vol. 81, no. 5, pp. 1269-1275, 2007.

[17] F. Kukulski, F. Ben Yebdri, J. Lecka et al., "Extracellular ATP and P2 receptors are required for IL- 8 to induce neutrophil migration," Cytokine, vol. 46, no. 2, pp. 166-170, 2009.

[18] F. B. Yebdri, F. Kukulski, A. Tremblay, and J. Sévigny, "Concomitant activation of P2Y2 and P2Y6 receptors on monocytes is required for TLR1/2-induced neutrophil migration by regulating IL-8 secretion," European Journal of Immunology, vol. 39, no. 10, pp. 2885-2894, 2009.

[19] F. Di Virgilio, "Purinergic mechanism in the immune system: a signal of danger for dendritic cells," Purinergic Signalling, vol. 1, no. 3, pp. 205-209, 2005.

[20] A. Trautmann, "Extracellular ATP in the immune system: more than just a "danger signal'”' Science Signaling, vol. 2, no. 56, article pe6, 2009.

[21] G. Y. Chen and G. Nuñez, "Sterile inflammation: Sensing and reacting to damage," Nature Reviews Immunology, vol. 10, no. 12, pp. 826-837, 2010.

[22] M. J. L. Bours, E. L. R. Swennen, F. Di Virgilio, B. N. Cronstein, and P. C. Dagnelie, "Adenosine 5 '-triphosphate and adenosine as endogenous signaling molecules in immunity and inflammation," Pharmacology and Therapeutics, vol. 112, no. 2, pp. 358404, 2006.

[23] F. Kukulski, S. A. Lévesque, and J. Sévigny, "Impact of ectoenzymes on P2 and P1 receptor signaling," Advances in Pharmacology, vol. 61, pp. 263-299, 2011.

[24] S. C. Robson, J. Sévigny, and H. Zimmermann, "The ENTPDase family of ectonucleotidases: structure function relationships and pathophysiological significance," Purinergic Signalling, vol. 2, no. 2, pp. 409-430, 2006.

[25] A. R. Beaudoin, J. Sévigny, and M. Picher, "ATP-diphosphohydrolases, apyrases, and nucleotide phosphohydrolases: biochemical properties and functions," in ATPases, A. G. Lee, Ed., pp. 369-401, JAI Press, Greenwich, UK, 1996.

[26] H. Zimmermann, M. Zebisch, and N. Sträter, "Cellular function and molecular structure of ecto-nucleotidases," Purinergic Signalling, vol. 8, no. 3, pp. 437-502, 2012.

[27] Q. Lu and M. Inouye, "Adenylate kinase complements nucleoside diphosphate kinase deficiency in nucleotide metabolism," Proceedings of the National Academy of Sciences of the United States of America, vol. 93, no. 12, pp. 5720-5725, 1996.

[28] S. James and P. J. Richardson, "Production of adenosine from extracellular ATP at the striatal cholinergic synapse," Journal of Neurochemistry, vol. 60, no. 1, pp. 219-227, 1993. 
[29] G. G. Yegutkin, "Nucleotide- and nucleoside-converting ectoenzymes: important modulators of purinergic signalling cascade," Biochimica et Biophysica Acta-Molecular Cell Research, vol. 1783, no. 5, pp. 673-694, 2008.

[30] M. T. Abreu-Martin, A. Vidrich, D. H. Lynch, and S. R. Targan, "Divergent induction of apoptosis and IL-8 secretion in HT-29 cells in response to TNF- $\alpha$ and ligation of Fas antigen," Journal of Immunology, vol. 155, no. 9, pp. 4147-4154, 1995.

[31] C. P. Kelly, S. Keates, D. Siegenberg, J. K. Linevsky, C. Pothoulakis, and H. R. Brady, "IL-8 secretion and neutrophil activation by HT-29 colonic epithelial cells," The American Journal of Physiology, vol. 267, no. 6, pp. G991-G997, 1994.

[32] T. A. Schneeman, M. E. C. Bruno, H. Schjerven, F. Johansen, L. Chady, and C. S. Kaetzel, "Regulation of the polymeric Ig receptor by signaling through TLRs 3 and 4: linking innate and adaptive immune responses," Journal of Immunology, vol. 175, no. 1, pp. 376-384, 2005.

[33] M. Höpfner, K. Lemmer, A. Jansen et al., "Expression of functional P2-purinergic receptors in primary cultures of human colorectal carcinoma cells," Biochemical and Biophysical Research Communications, vol. 251, no. 3, pp. 811-817, 1998.

[34] M. Höpfner, K. Maaser, B. Barthel et al., "Growth inhibition and apoptosis induced by $\mathrm{P}_{2} \mathrm{Y}_{2}$ receptors in human colorectal carcinoma cells: involvement of intracellular calcium and cyclic adenosine monophosphate," International Journal of Colorectal Disease, vol. 16, no. 3, pp. 154-166, 2001.

[35] H. Hu, L. M. O’Mullane, M. M. Cummins et al., "Negative regulation of $\mathrm{Ca}^{2+}$ influx during $\mathrm{P} 2 \mathrm{Y} 2$ purinergic receptor activation is mediated by $\mathrm{G} \beta \gamma$-subunits," Cell Calcium, vol. 47, no. 1, pp. 55-64, 2010.

[36] M. Sakowicz-Burkiewicz, A. Kitowska, M. Grden, I. Maciejewska, A. Szutowicz, and T. Pawelczyk, "Differential effect of adenosine receptors on growth of human colon cancer HCT 116 and HT-29 cell lines," Archives of Biochemistry and Biophysics, vol. 533, no. 1-2, pp. 47-54, 2013.

[37] T. Ren, Y. Qiu, and W. Wu, "Activation of adenosine A3 receptor alleviates TNF- $\alpha$-induced inflammation through inhibition of the NF- $\kappa$ B signaling pathway in human colonic epithelial cells," Mediators of Inflammation, vol. 2014, Article ID 818251, 11 pages, 2014.

[38] S. Merighi, A. Benini, P. Mirandola et al., "Caffeine inhibits adenosine-induced accumulation of hypoxia-inducible factor$1 \alpha$, vascular endothelial growth factor, and interleukin-8 expression in hypoxic human colon cancer cells," Molecular Pharmacology, vol. 72, no. 2, pp. 395-406, 2007.

[39] V. Lelièvre, J. Muller, and J. Falcòn, "Adenosine modulates cell proliferation in human colonic carcinoma. II. Differential behavior of HT29, DLD-1, Caco-2 and SW403 cell lines," European Journal of Pharmacology, vol. 341, no. 2-3, pp. 299308, 1998.

[40] V. Lelièvre, E. Caigneaux, J. Muller, and J. Falcón, "Extracellular adenosine deprivation induces epithelial differentiation of HT29 cells: Evidence for a concomitant adenosine A1/A2 receptor balance regulation," European Journal of Pharmacology, vol. 391, no. 1-2, pp. 21-29, 2000.

[41] J. Linden, "Adenosine metabolism and cancer. Focus on "Adenosine downregulates DPPIV on HT-29 colon cancer cells by stimulating protein tyrosine phosphatases and reducing ERK1/2 activity via a novel pathway'”,' The American Journal of Physiology-Cell Physiology, vol. 291, no. 3, pp. C405-C406, 2006.
[42] S. Gessi, S. Merighi, K. Varani et al., "Adenosine receptors in colon carcinoma tissues and colon tumoral cell lines: focus on the A3 adenosine subtype," Journal of Cellular Physiology, vol. 211, no. 3, pp. 826-836, 2007.

[43] F. Kukulski, S. A. Lévesque, É. G. Lavoie et al., "Comparative hydrolysis of P2 receptor agonists by NTPDases 1, 2, 3 and 8," Purinergic Signalling, vol. 1, no. 2, pp. 193-204, 2005.

[44] S. P. Colgan, H. K. Eltzschig, T. Eckle, and L. F. Thompson, "Physiological roles for ecto-5' -nucleotidase (CD73)," Purinergic Signalling, vol. 2, no. 2, pp. 351-360, 2006.

[45] N. Sträter, "Ecto-5/-nucleotidase: structure function relationships," Purinergic Signalling, vol. 2, no. 2, pp. 343-350, 2006.

[46] L. Collavin, D. Lazarevič, R. Utrera, S. Marzinotto, M. Monte, and C. Schneider, "wt p53 dependent expression of a membrane-associated isoform of adenylate kinase," Oncogene, vol. 18 , no. 43, pp. 5879-5888, 1999.

[47] M. Wirth, E. Berthold, M. Grashoff, H. Pfutzner, U. Schubert, and $\mathrm{H}$. Hauser, "Detection of mycoplasma contaminations by the polymerase chain reaction," Cytotechnology, vol. 16, no. 2, pp. 67-77, 1994.

[48] J. Pelletier, E. G. Lavoie, M. Fausther et al., "Production d'anticorps contre les NTPDases," 9e journée scientifique du CRRI. Hôtel-Musée Premières Nations, Wendake, Canada, Cahier des résumés, p. 31, 2010.

[49] J. Lecka, M. S. Rana, and J. Sévigny, "Inhibition of vascular ectonucleotidase activities by the pro-drugs ticlopidine and clopidogrel favours platelet aggregation," British Journal of Pharmacology, vol. 161, no. 5, pp. 1150-1160, 2010.

[50] X. Liu, L. Yu, Q. Wang et al., "Expression of ecto-ATPase NTPDase2 in human dental pulp," Journal of Dental Research, vol. 91, no. 3, pp. 261-267, 2012.

[51] M. N. Munkonda, J. Pelletier, V. V. Ivanenkov et al., "Characterization of a monoclonal antibody as the first specific inhibitor of human NTP diphosphohydrolase-3: partial characterization of the inhibitory epitope and potential applications," FEBS Journal, vol. 276, no. 2, pp. 479-496, 2009.

[52] A. A. Baykov, O. A. Evtushenko, and S. M. Avaeva, "A malachite green procedure for orthophosphate determination and its use in alkaline phosphatase-based enzyme immunoassay," Analytical Biochemistry, vol. 171, no. 2, pp. 266-270, 1988.

[53] J. Vaz and R. Andersson, "Intervention on toll-like receptors in pancreatic cancer," World Journal of Gastroenterology, vol. 20, no. 19, pp. 5808-5817, 2014.

[54] B. Fernandez-Garcia, N. Eiró, S. González-Reyes et al., "Clinical significance of toll-like receptor 3, 4, and 9 in gastric cancer," Journal of Immunotherapy, vol. 37, no. 2, pp. 77-83, 2014.

[55] S. Rakoff-Nahoum, J. Paglino, F. Eslami-Varzaneh, S. Edberg, and R. Medzhitov, "Recognition of commensal microflora by toll-like receptors is required for intestinal homeostasis," Cell, vol. 118, no. 2, pp. 229-241, 2004.

[56] W. Strober, "Epithelial cells pay a Toll for protection," Nature Medicine, vol. 10, no. 9, pp. 898-900, 2004.

[57] M. Vijay-Kumar, H. Wu, J. Aitken et al., "Activation of tolllike receptor 3 protects against DSS-induced acute colitis," Inflammatory Bowel Diseases, vol. 13, no. 7, pp. 856-864, 2007.

[58] R. Zhou, H. Wei, R. Sun, J. Zhang, and Z. Tian, "NKG2D recognition mediates Toll-like receptor 3 signaling-induced breakdown of epithelial homeostasis in the small intestines of mice," Proceedings of the National Academy of Sciences of the United States of America, vol. 104, no. 18, pp. 7512-7515, 2007. 
[59] A. E. Ostvik, A. Granlund, B. I. Gustafsson et al., "Mucosal toll-like receptor 3-dependent synthesis of complement factor $\mathrm{B}$ and systemic complement activation in inflammatory bowel disease," Inflammatory Bowel Diseases, vol. 20, no. 6, pp. 9951003, 2014.

[60] M. Picher and R. C. Boucher, "Human airway ecto-adenylate kinase: a mechanism to propagate ATP signaling on airway surfaces," Journal of Biological Chemistry, vol. 278, no. 13, pp. 11256-11264, 2003.

[61] T. Henttinen, S. Jalkanen, and G. G. Yegutkin, "Adherent leukocytes prevent adenosine formation and impair endothelial barrier function by Ecto- $5^{\prime}$-nucleotidase/CD73-dependent mechanism," Journal of Biological Chemistry, vol. 278, no. 27, pp. 24888-24895, 2003.

[62] J. Linden, "Adenosine in tissue protection and tissue regeneration," Molecular Pharmacology, vol. 67, no. 5, pp. 1385-1387, 2005.

[63] M. P. Abbracchio and S. Ceruti, "P1 receptors and cytokine secretion," Purinergic Signalling, vol. 3, no. 1-2, pp. 13-25, 2007.

[64] R. Kruse, I. Demirel, S. Säve, and K. Persson, "IL-8 and global gene expression analysis define a key role of ATP in renal epithelial cell responses induced by uropathogenic bacteria," Purinergic Signal, 2014. 


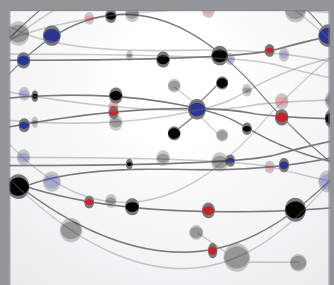

The Scientific World Journal
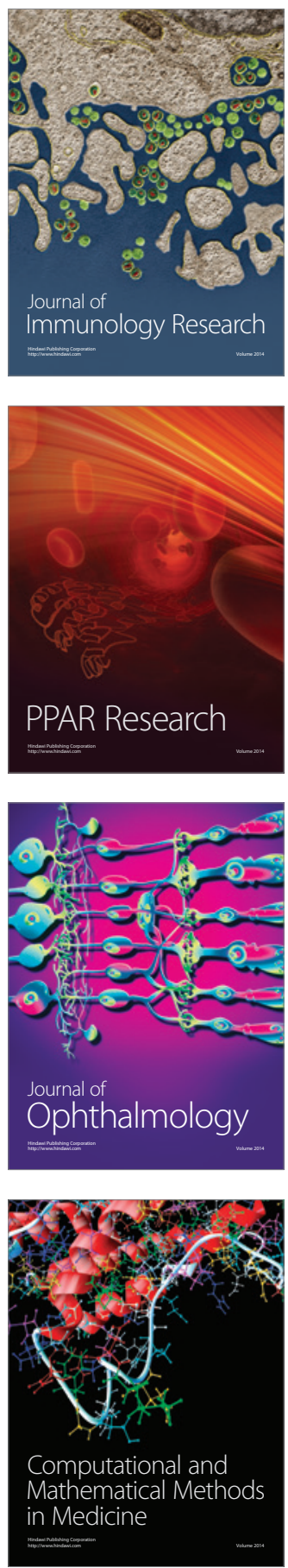

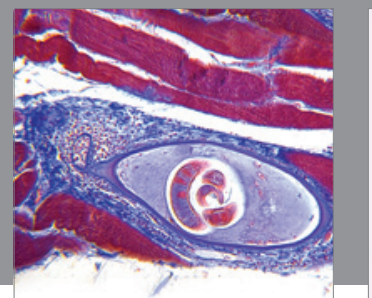

Gastroenterology

Research and Practice
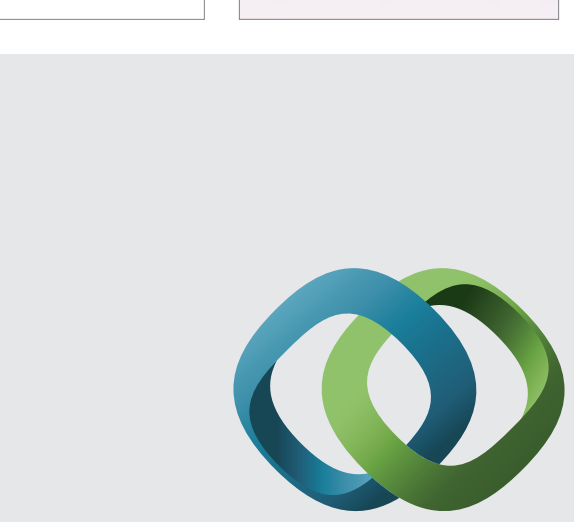

\section{Hindawi}

Submit your manuscripts at

http://www.hindawi.com
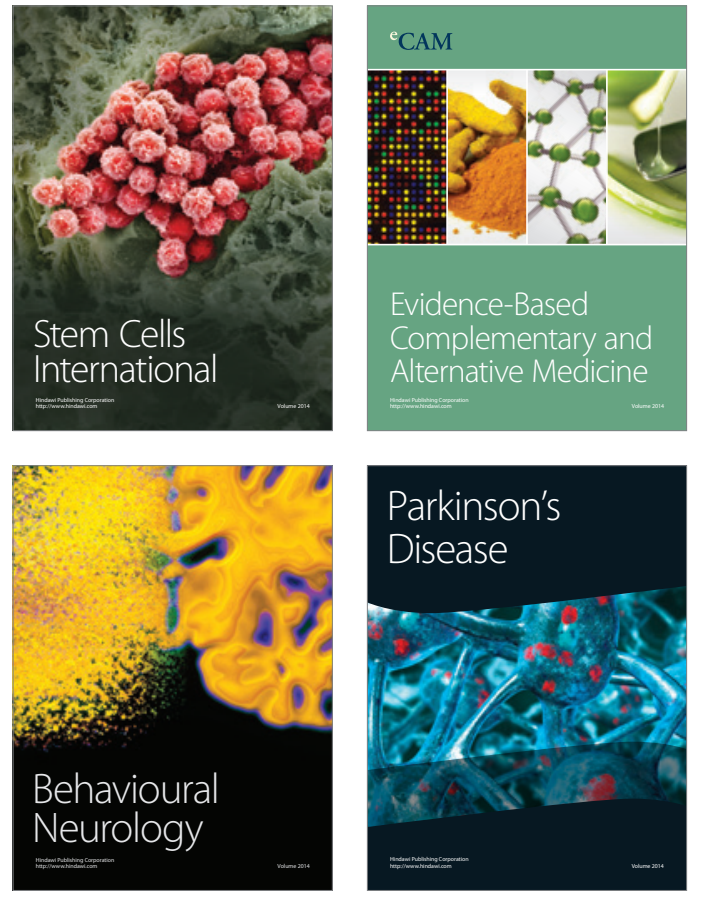
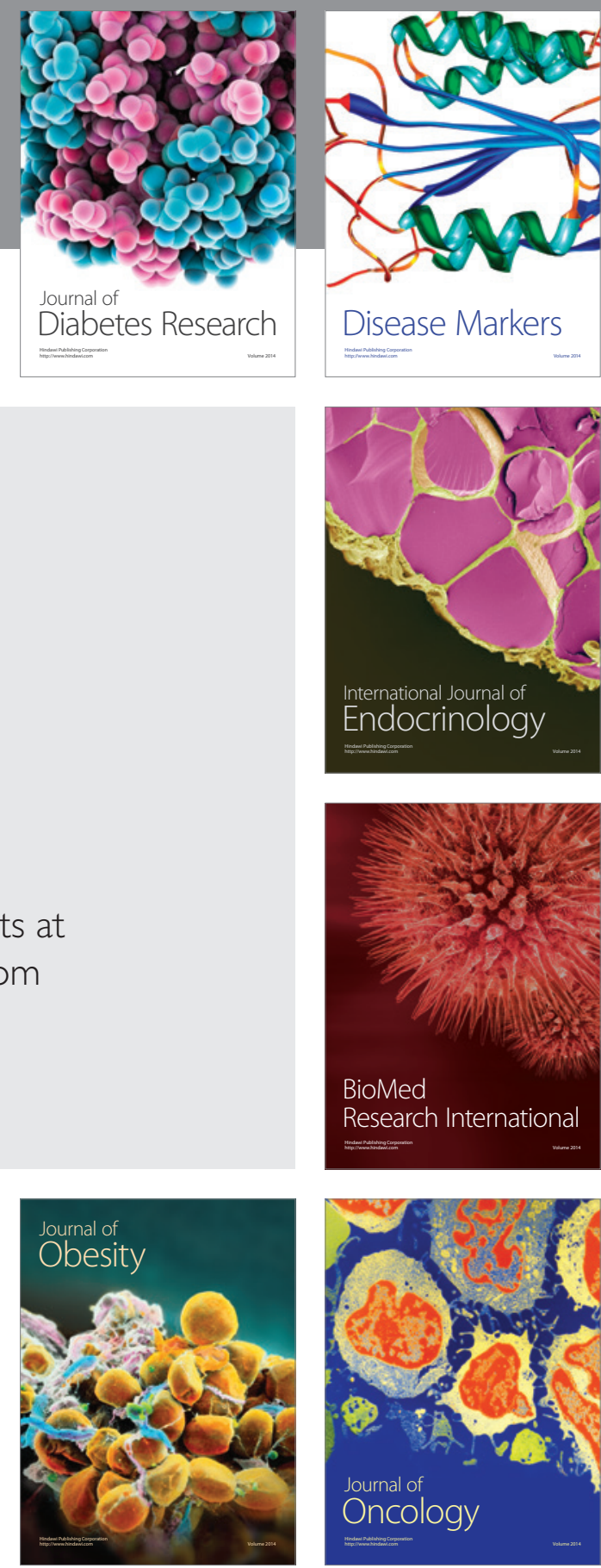

Disease Markers
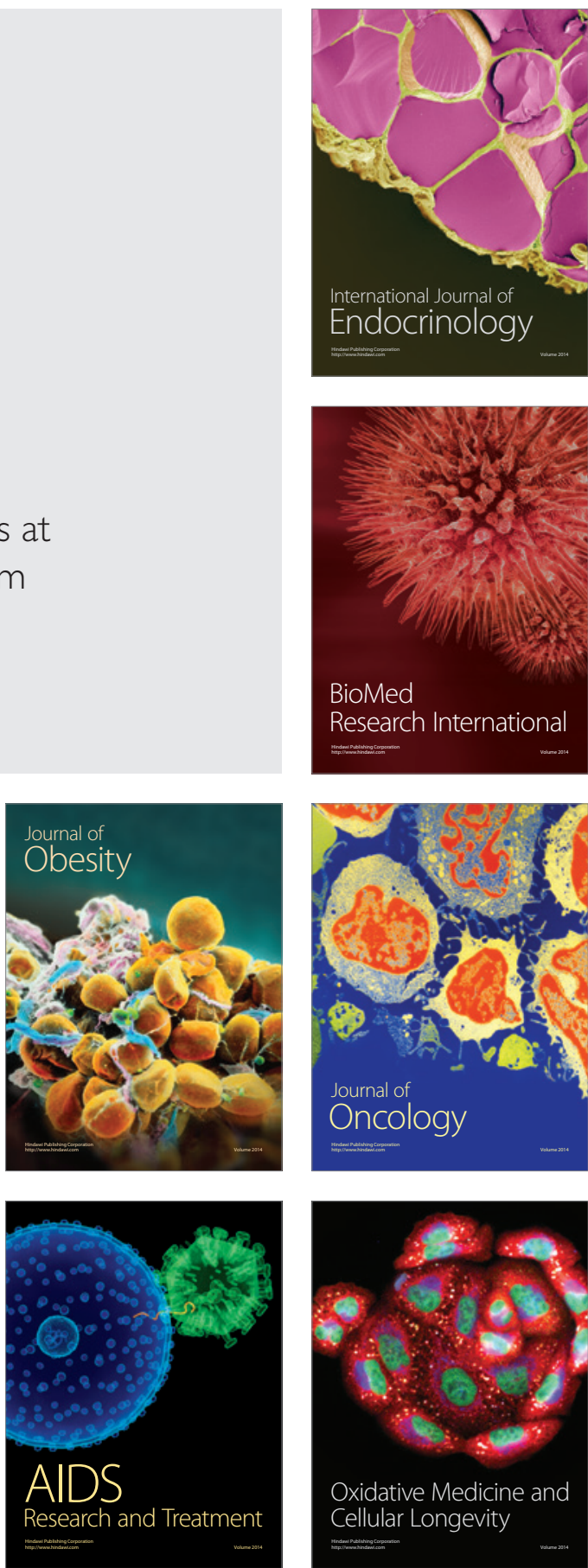